The Modernity of Others 
Stanford Studies in Jewish History and Culture edited в Aron Rodrigue and Steven J. Zipperstein 


\section{The Modernity of Others}

Jewish Anti-Catholicism in Germany and France

Ari Joskowicz 
Stanford University Press

Stanford, California

(C) 2014 by the Board of Trustees of the Leland Stanford Junior University.

All rights reserved.

Published with assistance from the College of Arts and Science at Vanderbilt University.

No part of this book may be reproduced or transmitted in any form or by any means, electronic or mechanical, including photocopying and recording, or in any information storage or retrieval system without the prior written permission of Stanford University Press.

Printed in the United States of America on acid-free, archival-quality paper

Library of Congress Cataloging-in-Publication Data

Joskowicz, Ari, author.

The modernity of others: Jewish anti-Catholicism in Germany and France / Ari Joskowicz.

pages $\mathrm{cm}$

Includes bibliographical references and index.

ISBN 978-0-8047-8702-4 (cloth : alk. paper)

I. Anti-Catholicism-Germany-History-I9th century. 2. Anti-CatholicismFrance-History-19th century. 3. Anti-clericalism-Germany-HistoryI9th century. 4. Anti-clericalism-France-History-igth century. 5. JewsGermany-Politics and government-I9th century. 6. Jews-France-Politics and government-I9th century. 7. Secularism-Europe-History-I9th century. I. Title.

BXI766.J67 20I3

305.892'404-dc23

2013013482

Typeset by Thompson Type in I0 1/2/14 Galliard 
To my parents 
